\title{
Responses of oyster Crassostrea virginica hemocytes to environmental and clinical isolates of Vibrio parahaemolyticus
}

\author{
Aswani K. Volety ${ }^{1}$, Susan A. McCarthy ${ }^{2}$, Ben D. Tall ${ }^{3}$, Sherill K. Curtis ${ }^{3}$, \\ William S. Fisher ${ }^{4}$, Fred J. Genthner ${ }^{4, *}$ \\ ${ }^{1}$ Florida Gulf Coast University, 10501 FGCU Blvd., Fort Myers, Florida 33965, USA \\ ${ }^{2}$ US Food and Drug Administration, Center for Food Safety and Applied Nutrition, Dauphin Island, Alabama 36528, USA \\ ${ }^{3}$ US Food and Drug Administration, Center for Food Safety and Applied Nutrition, Washington, DC 20204, USA \\ ${ }^{4}$ US Environmental Protection Agency, National Health and Environmental Effects Research Laboratory, \\ Gulf Ecology Division, Gulf Breeze, Florida 32561, USA
}

\begin{abstract}
Ingestion of bacteria by oysters Crassostrea virginica and bactericidal activity of oyster hemocytes were studied using 4 environmental isolates (shellfish) and 3 clinical isolates (fecal) of Vibrio parahaemolyticus. Clinical isolates $(2030,2062,2107)$ were obtained from the feces of patients with gastroenteritis who became ill during the 1998 food poisoning outbreak traced to consumption of raw oysters from Galveston Bay, Texas. This outbreak was the first reported occurrence in the United States of the virulent serotype O3:K6. Environmental isolates were from oysters $(1094,1100)$, crab (1163) and sardines (ATCC 17802). All isolates possessed the thermolabile direct hemolysin (tlh) gene, whereas only the clinical isolates possessed the thermostable direct hemolysin $(t d h)$ gene, a virulence determinant. On average, environmental isolates were more susceptible than clinical isolates to killing by oyster hemocytes, as determined by an in vitro dye reduction assay. Isolate 2062 was the most susceptible of the clinical isolates; it lacked identifiable capsular material present in the other clinical isolates and displayed the most diffuse colony morphology on nutrient agar plates. When oysters were exposed in vivo to mixtures of a clinical (2030) and an environmental (1163) isolate, more clinical than environmental isolates were found in the tissues and hemolymph.
\end{abstract}

KEY WORDS: Oyster · Vibrio parahaemolyticus $\cdot$ Hemocytes · Capsule

\section{INTRODUCTION}

Vibrio parahaemolyticus, ubiquitous in marine and estuarine environments (Chowdhury et al. 1990), is commonly associated with shellfish (Earle \& Crisley 1975, Varga \& Hirtle 1975, DePaola et al. 1990). In general, Vibrio spp. in shellfish and estuarine waters favor high temperatures and low to moderate salinity (Tamplin et al. 1982, Oliver et al. 1983, Tamplin 1994, Motes et al. 1998). In humans who eat uncooked seafood,

${ }^{*}$ Cooresponding author. E-mail: genthner.fred@epa.gov
$V$. parahaemolyticus can cause severe gastroenteritis (Blake et al. 1980, Janda et al. 1988). In the summer of 1998, V. parahaemolyticus was implicated in a gastroenteritis outbreak involving 416 cases in 16 States. Illnesses were traced to the consumption of raw oysters harvested from Galveston Bay, TX; clinical isolates from 28 patients were serotype O3:K6 (Daniels et al. 1999). This was the first report in the United States of serotype O3:K6, which was previously found only in Asia (Okuda et al. 1997, Bag et al. 1999). This serotype was not recovered from any oysters subsequently harvested from Galveston Bay (Kirk Wiles, Texas Department of Health, pers. comm.). 
Oyster gill cilia generate an incurrent water flow (4 to $40 \mathrm{l} \mathrm{h}^{-1}$ oyster $^{-1}$ ) that draws suspended material into the oyster pallial (mantle) cavity (Galtsoff 1964). This inflow contains a variety of microorganisms that are either suspended or adsorbed to phytoplankton and other particulate matter. These microorganisms may be eliminated from the pallial cavity through excurrent flow, production of pseudofeces (a mixture of oyster mucus and particulate material), or phagocytosis by hemocytes in the external mucus (Allam et al. 2000). Alternatively, microorganisms can be ingested by the oyster, leading to their destruction within the digestive gland or elimination in feces. However, some microorganisms persist in the oyster through either adhesion or invasion of tissues.

Several depuration (controlled purification) studies have shown that oysters do not eliminate all microorganisms equally. Enteric bacteria (e.g., Escherichia coli, fecal coliforms, Salmonella spp.) are eliminated quite effectively (Barrow \& Miller 1969, Son \& Fleet 1980, Jones et al. 1991), whereas viruses (Metcalf et al. 1979, Richards 1988, Power \& Collins 1989) and indigenous estuarine vibrios (Greenberg et al. 1982, Eyles \& Davey 1984, Fletcher et al. 1991, Jones et al. 1991, Tamplin \& Capers 1992) are less consistently eliminated. In fact, Tamplin \& Capers (1992) reported that Vibrio vulnificus in oysters held at $23^{\circ} \mathrm{C}$ can persist and replicate at a rate that allows the release of $10^{5}$ bacteria oyster ${ }^{-1} \mathrm{~h}^{-1}$. This is a critical concern because of serious human diseases and fatalities associated with the consumption of shellfish containing viruses and vibrios (Richards 1988).

Microorganisms that persist in oysters must overcome an antimicrobial defense system that consists of cellular and humoral factors (Chu 1988, Feng 1988) that can act internally and externally. The defensive blood cells (hemocytes) can move from hemolymph sinuses across epithelial barriers (diapedesis) into tissues, digestive tract or pallial cavity (Fisher 1986). Although little is known of their in vivo bactericidal ability, oyster hemocytes tested in vitro are known to kill several species of bacteria, including different strains of Vibrio parahaemolyticus and V. vulnificus (Harris-Young et al. 1993, 1995, Genthner et al. 1999). These studies showed that hemocyte killing ability varied with different bacterial species and revealed an association between bacterial susceptibility to hemocytes and the degree of bacterial encapsulation. Bacteria with an outer polysaccharide capsule were found to be less susceptible than nonencapsulated isolates to killing by oyster hemocytes. Harris-Young et al. (1995) showed that virulent (encapsulated, opaque colonies) $V$. vulnificus were less readily phagocytized by oyster hemocytes and were more resistant to degradation after phagocytosis than an avirulent strain (nonencap- sulated, translucent colonies). Presence of a bacterial capsule, at least for $V$. vulnificus, was associated with resistance to phagocytosis in mammals, and several capsular characteristics were postulated as virulence factors for human disease (Tamplin et al. 1985, Yoshida et al. 1985, Simpson et al. 1987, Wright et al. 1990, Wright \& Morris 1991).

Many studies of the association of Vibrio spp. with shellfish have concentrated on V. vulnificus (De Paola et al. 1997, Motes et al. 1998). However, interest in $V$. parahaemolyticus increased with the emergence of the virulent O3:K6 serotype in the United States (Daniels et al. 1999). V. parahaemolyticus isolates, of both environmental and clinical origin, produce a species-specific thermolabile direct hemolysin (tlh) (Tanaguchi et al. 1985) that can be used to confirm identification. A thermostable direct hemolysin $(t d h)$, which is associated with production of beta-hemolysis on Wagatsuma agar (Kanagawa phenomenon) (Honda et al. 1988, Wong et al. 2000), is produced by pathogenic isolates. Food and environmental isolates that are not pathogenic to humans do not possess the $t d h$ gene (Shirai et al. 1990).

Remaining unresolved are the relations among various factors, including the persistence of Vibrio parahaemolyticus in oysters, the resistance of this organism to phagocytosis, possession of the tdh gene and the expression of virulence factors such as capsules. The purpose of this study was to compare virulent clinical isolates (serotype 03:K6) from the 1998 Galveston outbreak with various environmental isolates in relation to their degree of encapsulation, ingestion by oysters and susceptibility to phagocytosis by oyster hemocytes.

\section{MATERIALS AND METHODS}

Bacterial isolates used in this study. Three environmental isolates of Vibrio parahaemolyticus from shellfish (1094, 1100 and 1163) were compared with 3 clinical isolates (2030, 2062 and 2107) cultured from stool samples of patients afflicted with gastroenteritis after eating oysters from Galveston Bay (Table 1). To permit identification of individual isolates during in vivo oyster exposure experiments, spontaneous streptomycin-resistant derivatives of $V$. parahaemolyticus 1163 and 2030 were selected and denoted 1163 S and 2030S, respectively. From these derivatives, spontaneous nalidixic acid-resistant derivatives (1163SN and 2030SN) were selected. Spontaneous rifampicin-resistant derivatives (1163SR and 2030SR) were also selected from the streptomycin-resistant derivatives. In addition, ATCC type strain 17802 (Fujino et al. 1974) and a transposon mutant (LM4462 Fix-Tra) that is unable to switch to an opaque phenotype were used as references. 
Table 1. Vibrio parahaemolyticus isolates used in this study

\begin{tabular}{|lll|}
\hline Bacterial isolate & Relevant characteristics & Source \\
\hline 1094 & Environmental isolate, raw oyster & W. Landry, Food and Drug Administration, Dallas, TX \\
1100 & Environmental isolate, raw oyster & Food and Drug Administration, Dauphin Island, AL \\
1163 & Environmental isolate, raw crab & W. Landry, Food and Drug Administration, Dallas, TX \\
$1163 \mathrm{~S}$ & Resistant to streptomycin & This study; derivative of 1163 \\
$1163 \mathrm{SR}$ & Resistant to rifampicin & This study; derivative of 1163S \\
$1163 \mathrm{SN}$ & Resistant to nalidixic acid & This study; derivative of 1163S \\
2030 & Stool sample from patient with gastroenteritis & K. Wiles, Texas Department of Health, Austin, TX \\
$2030 \mathrm{~S}$ & Resistant to streptomycin & This study; derivative of 2030 \\
$2030 \mathrm{SR}$ & Resistant to rifampicin & This study; derivative of 2030S \\
$2030 \mathrm{SN}$ & Resistant to nalidixic acid & This study; derivative of 2030S \\
2062 & Stool sample from patient with gastroenteritis & K. Wiles, Texas Department of Health, Austin, TX \\
2107 & Stool sample from patient with gastroenteritis & K. Wiles, Texas Department of Health, Austin, TX \\
17802 & ATCC Type Strain & Fujino et al. (1974) \\
LM4462 (Fix-Tra) & Translucent strain unable to switch to opaque & McCarter (1998) \\
& & \\
\hline
\end{tabular}

Bacterial culture conditions. Initially, all isolates and derivatives were cultured in nutrient broth (Difco Laboratories, Detroit, MI) supplemented with $2 \% \mathrm{NaCl}$ (NBS). Filtered seawater (FSW) for medium preparation was collected from Santa Rosa Sound (near Pensacola Beach, FL), adjusted with distilled water to 20 ppt salinity, sterilized by filtration $(0.22 \mu \mathrm{m})$ and maintained at $25^{\circ} \mathrm{C}$. Bacteria were inoculated into $125 \mathrm{ml}$ Erlenmeyer flasks containing $10 \mathrm{ml}$ of NBS and incubated for $18 \mathrm{~h}$ at $25^{\circ} \mathrm{C}$ with shaking (200 rpm). Numbers and colony morphology of culturable bacteria were determined by the spread plate method ( $0.1 \mathrm{ml}$ aliquots) after 18 to $36 \mathrm{~h}$ of growth at $25^{\circ} \mathrm{C}$ on NBS agar $(1.5 \%)$ plates. For oyster exposure and hemocyte killing tests, dilutions of challenge bacteria were made in FSW. For detection of hemolysin genes, cultures were prepared and maintained as described previously (McCarthy et al. 1999). For examination by electron microscopy, bacteria were grown in trypticase soy broth (Difco) supplemented with $1 \%$ $\mathrm{NaCl}$ for $18 \mathrm{~h}$ at $30^{\circ} \mathrm{C}$ with shaking (200 rpm).

Bacterial characterization. Bacterial DNA was extracted following the method of Gannon et al. (1992). Dried DNA pellets were resuspended in $20 \mu \mathrm{l}$ of sterile Milli-Q water. For PCR, reaction mixtures contained $10 \mu \mathrm{l}$ of $10 \times \mathrm{PCR}$ reaction buffer, $10 \mu \mathrm{l}$ of $25 \mathrm{mM} \mathrm{MgCl}_{2}$, $200 \mu \mathrm{M}$ deoxyribonucleoside-5' -triphosphates, 2.5 units AmpliTaq DNA polymerase, $1 \mu \mathrm{M}$ of each primer, and $20 \mu \mathrm{l}$ DNA extract (final volume: $100 \mu \mathrm{l}$ ). Cycling parameters consisted of initial denaturation at $94^{\circ} \mathrm{C}$ for $3 \mathrm{~min}$ followed by 30 cycles of denaturation at $94^{\circ} \mathrm{C}$ for $1 \mathrm{~min} ; 60^{\circ} \mathrm{C}$ for $1 \mathrm{~min}$; and $72^{\circ} \mathrm{C}$ for $2 \mathrm{~min}$. Final extension was at $72^{\circ} \mathrm{C}$ for $7 \mathrm{~min}$. Twenty microliters of PCRamplified DNA was separated in a $1 \%$ agarose gel and stained with ethidium bromide. The primer sequences used for amplification of $t l h$ and $t d h$ genes were as follows: th-L, 5'AAA GCG GAT TAT GCA GAA GCA CTG3' and tlh-R, 5' GCT ACT TTC TAG CAT TTT
CTC TGC3' (Taniguchi et al. 1986); tdh-L, 5'GTA AAG GTC TCT GAC TTT TGG AC3' and $t d h-\mathrm{R}, 5^{\prime}$ 'TGG AAT AGA ACC TTC ATC TTC ACC3' (Nishibuchi \& Kaper 1985). Gene probes labeled with alkaline phosphatase (AP) and digoxigenin (DIG) were prepared as described previously and used to identify Vibrio parahaemolyticus (McCarthy et al. 1999, 2000).

Electron microscopy. Bacterial cells were harvested from overnight broth cultures by centrifugation (14000 $\times$ $g, 5 \mathrm{~min}, 4^{\circ} \mathrm{C}$ ) or by scraping growth from trypticase soy (plus $1 \% \mathrm{NaCl}$ ) agar plates. In accordance with a procedure developed by Fassel et al. (1992), cells were prefixed in $2.5 \%$ glutaraldehyde in $0.1 \mathrm{M}$ sodium cacodylate buffer (SCB) with $75 \mathrm{mM}$ lysine and $0.075 \%$ alcian blue for $20 \mathrm{~min}$ on ice. Additional processing for transmission electron microscopy (TEM) was performed as described by Miliotis et al. (1995) except that the samples were fixed on ice for $2 \mathrm{~h}$ in $2.5 \%$ glutaraldehyde in $0.1 \mathrm{M} \mathrm{SCB}$ with $0.075 \%$ alcian blue, washed 3 times in $0.1 \mathrm{M} \mathrm{SCB}$ (5 min for each washing step) and postfixed in $1 \% \mathrm{OSO}_{4}$ in $0.1 \mathrm{M} \mathrm{SCB}$ for $2 \mathrm{~h}$ on ice. Control material was processed through the previously described steps without exposure to reagents containing alcian blue or lysine. All of the samples were again washed in $0.1 \mathrm{SCB}$ ( $5 \mathrm{~min}$ ) and embedded in $2 \%$ agar. Agar blocks were cut into $3 \mathrm{~mm}$ cubes and dehydrated in an ascending ethanol graded series $(30,50,70,90,95$ and $100 \%$; 5 min at each concentration) followed by clearing for $30 \mathrm{~min}$ in propylene oxide. Samples were infiltrated with equal volumes of propylene oxide and Eponate 812 (Ted Pella, Inc., Reading, CA), and then polymerized in fresh Eponate 812 for $3 \mathrm{~d}$ at $60^{\circ} \mathrm{C}$. Ultrathin sections were made using a Leica Ultracut S ultramicrotome (Leica Microsystems Inc., Bannockburn, IL) and stained with uranyl acetate and lead citrate as described by Reynolds (1963). Preparations were examined using a Philips 400HM TEM operating at an acceleration voltage of $80 \mathrm{kV}$. 
Oyster collection and maintenance. Oysters (6.5 to $12.5 \mathrm{~cm}$ length) were collected from Bayou Texar, an inlet of Escambia Bay, FL, and transported to the US Environmental Protection Agency's Gulf Ecology Division Laboratory at Pensacola Beach, FL, during May 1999. Ambient salinity at the collection site ranged from 5 to 15 ppt. Oysters were held in $1900 \mathrm{l}$ holding tanks with flow-through unfiltered seawater (salinity 15 to $20 \mathrm{ppt}$ ) for 1 to 21 days.

Hemolymph collection. For in vitro killing assays, whole oyster hemolymph was collected using a syringe and 23 gauge needle inserted into the adductor muscle through a notch in the oyster shell. Hemolymph was collected in polypropylene tubes and immediately placed on ice to reduce hemocyte clumping. Hemolymph samples from 10 oysters were pooled for each trial.

In vitro killing assay. The percentage of bacteria killed in vitro by oyster hemocytes (killing index, KI) was determined in flat-bottomed 96 well microtiter plates as described by Volety et al. (1999), except that streptomycin was not used. Briefly, $10^{6}$ bacteria were incubated $\left(3 \mathrm{~h}, 17^{\circ} \mathrm{C}\right)$ with $10^{5}$ oyster hemocytes in each of 8 replicate wells. A growout period $\left(2 \mathrm{~h}, 25^{\circ} \mathrm{C}\right)$ for surviving bacteria was initiated by addition of NBS growth medium. The tetrazolium dye 3-(4,5-dimethylthiazol-2-yl)-5-(3-carboxymethoxyphenyl)-2-(4-sulfophenyl)-2H-tetrazolium (MTS; Promega Corporation, Madison, WI) and phenylmethasulfazone (PMS; Sigma Chemical Company, St. Louis, MO) were added to the wells $\left(30 \mathrm{~min}, 25^{\circ} \mathrm{C}\right.$ ), and the absorbencies of formazan, the soluble reduction product of MTS/PMS, were read (490 nm) using an ELISA microplate reader (Model 311-SX, Bio-Tek Instruments, Inc., Winooski, VT). The percentage of KI was calculated as described by Volety et al. (1999), using the average of 8 replicates.

In vivo exposure of oysters to environmental and clinical Vibrio parahaemolyticus isolates. Ten oysters were removed from the holding tank, and their shells were scrubbed with a brush using $10 \%$ bleach and rinsed thoroughly with FSW. Five oysters were placed in each of two 13 l, high-density polyethylene buckets containing $10 \mathrm{l}$ of FSW at $22^{\circ} \mathrm{C}$ and fed a single ration of algal paste $(0.25 \mathrm{~g})$. Aeration was provided to all containers. Bacteria from overnight NBS cultures were added to 1 tank containing oysters at a density of $\sim 1 \times$ $10^{6}$ cells $\mathrm{ml}^{-1}$. Oysters in the second tank served as the control group. The inoculum contained unequal numbers of antibiotic-resistant derivatives of clinical isolate 2030 and environmental isolate 1163. Derivatives 2030SR and 1163SN (initial density of $9.6 \times 10^{5} \mathrm{CFU}$ $\mathrm{ml}^{-1}$ ) were used in the first trial, and derivatives 2030SN and 1163SR (initial density of $8.1 \times 10^{5} \mathrm{CFU} \mathrm{m}^{-1}$ ) were used in the second trial. A water sample was collected from experimental and control tanks $(t=0)$. Appropriate dilutions $(0.1 \mathrm{ml})$ were spread on thiosulfate-citrate- bile-sucrose (TCBS) agar plates, selective for enteropathogenic vibrios. After incubation $\left(24 \mathrm{~h}, 25^{\circ} \mathrm{C}\right)$ colonies that formed on these plates were processed, as described below for oyster tissue, to differentiate between the clinical and environmental isolates.

After $48 \mathrm{~h}$, oysters in both the experimental and control groups were removed from the tanks, and their shells were brushed again with bleach. Hemolymph was collected from each oyster, followed by removal of all soft tissue, which was homogenized for $30 \mathrm{~s}$ using a Polytron (Brinkman Industries, Rexdale, Ontario, Canada). Aliquots $(0.1 \mathrm{ml})$ of both diluted hemolymph and tissue homogenates were spread in triplicate on TCBS agar plates. After incubation $\left(24 \mathrm{~h}, 25^{\circ} \mathrm{C}\right) 100$ randomly selected colonies were transferred using sterile toothpicks to NBS agar plates containing nalidixic acid (5 $\mu \mathrm{g}$ $\left.\mathrm{ml}^{-1}\right)$, rifampicin $\left(100 \mu \mathrm{g} \mathrm{ml}^{-1}\right)$ or streptomycin $(250 \mu \mathrm{g}$ $\left.\mathrm{ml}^{-1}\right)$. After incubation $\left(18 \mathrm{~h}, 25^{\circ} \mathrm{C}\right)$, the percentage of clinical isolates was determined based on antibiotic resistance phenotypes.

Statistical analysis. One-factor analyses of variance followed by a multiple comparison test (Tukey) was used to determine significant differences in KI among strains by oyster hemocytes. A Student's t-test was used to determine the differences in percentage of clinical and environmental isolates in the water at $t=0$ and in tissue or hemolymph after $48 \mathrm{~h}$ of incubation. Results were deemed significant at $\mathrm{p}<0.05$.

\section{RESULTS}

\section{Bacterial characterization}

The presence of the th gene in the environmental and clinical Vibrio parahaemolyticus isolates was established by PCR and by hybridization with AP- and DIG-labeled th gene probes. The $t d h$ gene was detected with both probes only in the clinical isolates 2030, 2062 and 2107 (Table 2). For both genes, the results obtained with the probes agreed $100 \%$ with the results obtained by PCR.

Colonial morphologies of the Vibrio parahaemolyticus isolates varied greatly after $24 \mathrm{~h}$ incubation at $25^{\circ} \mathrm{C}$ on NBS agar plates (Fig. 1). One isolate (1100) cultured from Mobile Bay oysters produced the smallest (2 to $3 \mathrm{~mm}$ diameter) and densest colonies. Colonies of ATCC type strain 17802 resembled those of the Mobile Bay isolate (data not shown). Environmental isolate 1163 produced slightly larger colonies with very irregular edges; environmental isolate 1094 produced the largest (10 to $15 \mathrm{~mm}$ diameter), most diffuse colonies. Of the clinical isolates, 2107 produced the largest (15 to $20 \mathrm{~mm}$ diameter), most diffuse colonies, and isolate 2062 produced the smallest (8 to $10 \mathrm{~mm}$ diameter) and densest colonies. 
Table 2. Detection of th and tdh genes in Vibrio parahaemolyticus isolates. AP: alkaline phosphatase-labeled probe; DIG: digoxigenin-labeled probe; tlh: thermolabile hemolysin gene; $t d h$ : thermostable direct hemolysin gene

\begin{tabular}{|lcccccc|}
\hline \multicolumn{7}{l}{ Isolate } \\
\hline \multicolumn{7}{l}{ Environmental } \\
1094 & + & + & + & - & - & - \\
1163 & + & + & + & - & - & - \\
Clinical & & & & & & \\
2030 & + & + & + & + & + & + \\
2062 & + & + & + & + & + & + \\
2107 & + & + & + & + & + & + \\
\hline
\end{tabular}

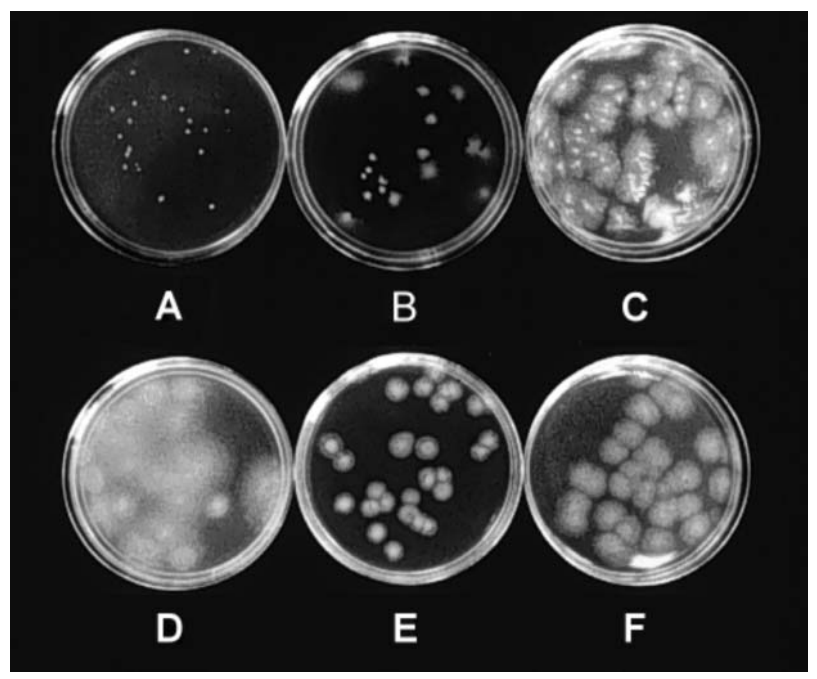

Fig. 1. Colonies of Vibrio parahaemolyticus isolates on nutrient agar $+2 \% \mathrm{NaCl}$ (NBS) medium. Dilutions of broth cultures were spread onto the agar surface and incubated at $25^{\circ} \mathrm{C}$ for 24 h. (A) Environmental isolate 1100, (B) environmental isolate 1163, (C) environmental isolate 1094, (D) clinical isolate 2107, (E) clinical isolate 2062 and (F) clinical isolate 2030

Growth media influenced the production of apparent polysaccharide, or capsular, material by Vibrio parahaemolyticus (Table 3); visualization of the material by electron microscopy was enhanced with alcian blue staining (Fig. 2). For example, in the absence of

Table 3. Presence (+) or absence (-) of capsular material in Vibrio parahaemolyticus isolates cultured on liquid (L) and solid (S) media and stained with or without alcian blue

\begin{tabular}{|lcc|}
\hline Isolate & Without alcian blue & With alcian blue \\
\hline 1094 & - & $+(\mathrm{L})$ \\
1163 & - & - \\
2030 & - & $+(\mathrm{L}, \mathrm{S})$ \\
2062 & - & - \\
2107 & $+(\mathrm{L})$ & $+(\mathrm{L}, \mathrm{S})$ \\
\hline
\end{tabular}

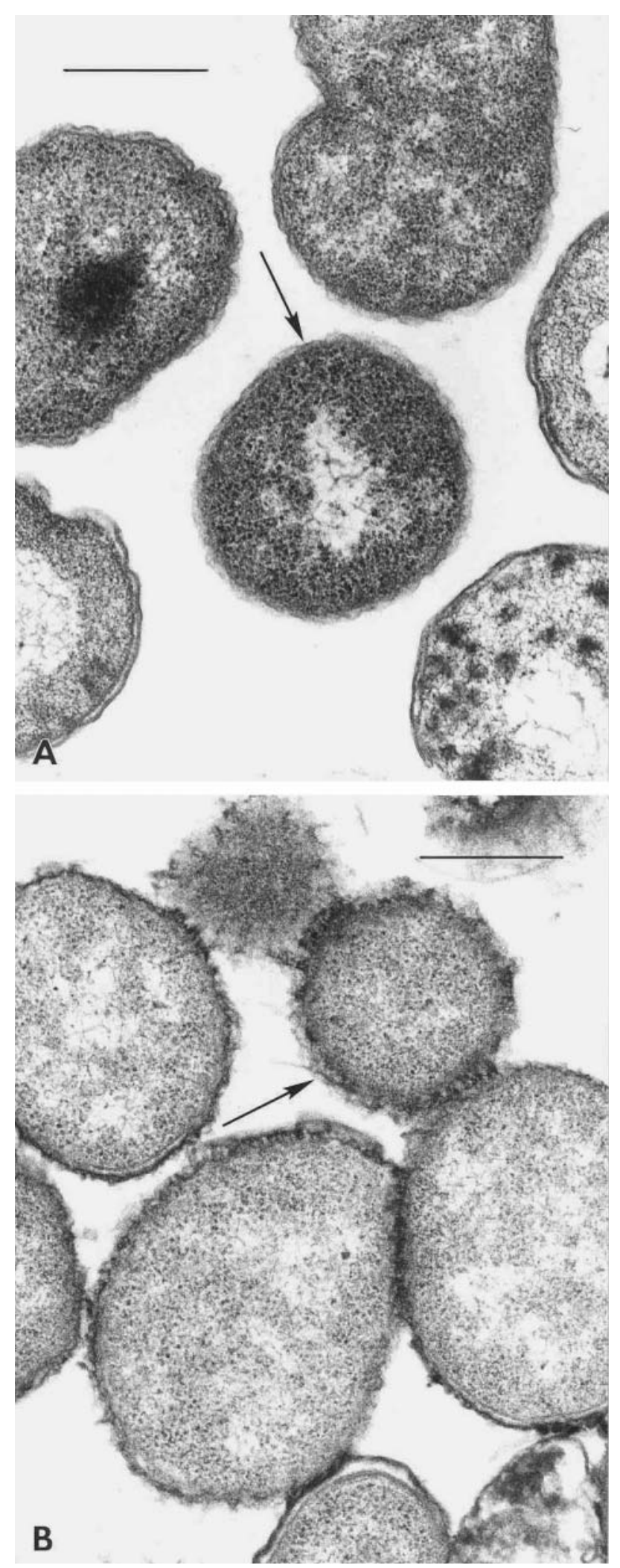

Fig. 2. Transmission electron micrographs of Vibrio parahaemolyticus isolate 2030. (A) Capsular material not visible without alcian blue stain; (B) visible capsules (dark spike-like structures on the cell surface) using alcian blue stain. Scale Bar $=0.5 \mu \mathrm{m}$ 

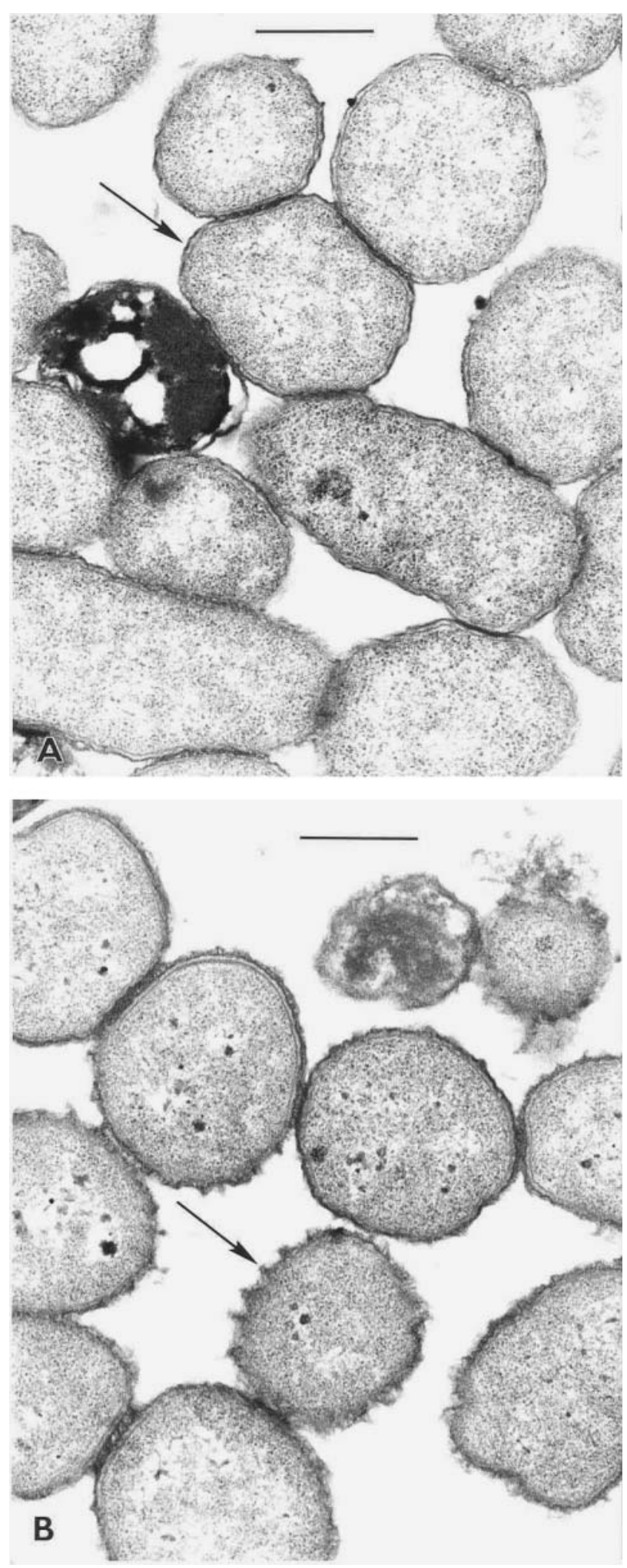

Fig. 3. Transmission electron micrographs of Vibrio parahaemolyticus cells preserved and stained with glutaraldehyde containing lysine with alcian blue. (A) Clinical isolate 2062 lacking capsules; (B) clinical isolate 2107 possessing capsules. Scale bar $=0.5 \mu \mathrm{m}$ alcian blue, only clinical isolate 2107 grown in liquid medium displayed discernible capsular material. In the presence of alcian blue, capsular material could be found in environmental isolate 1094 grown in liquid medium and in clinical isolates 2030 and 2107 grown either in liquid or solid medium. In contrast, environmental isolate 1163 and clinical isolate 2062 did not display capsular material regardless of the medium or staining conditions (Fig. 3). Clinical isolate 2107, which produced the most translucent, diffuse colonies on solid medium, exhibited the most capsular material (Fig. 3).

\section{Killing assay}

Significant differences in susceptibility were observed among the 7 Vibrio parahaemolyticus isolates challenged with oyster hemocytes in vitro (Fig. 4). Environmental isolate 1163 was significantly more susceptible to killing by hemocytes, with a higher KI than isolate 1094. Among the clinical isolates, strain 2062 was more susceptible to hemocyte killing, but differences in KI among the clinical strains were not significant. KI of the 3 clinical isolates was significantly lower than KI of the 4 environmental isolates tested, including ATCC 17802 and LM 4462 Fix-Tra.

\section{In vivo oyster exposure to environmental and clinical isolates}

Derivatives of 1163 and 2030 were selected because the in vitro studies showed that 1163, an environmental isolate, was most susceptible to killing by oyster hemocytes while 2030, a clinical isolate, was the least susceptible (Fig. 4). Strains were selected for resistance to 2 antibiotics and used in 2 separate exposures to reduce the possibility of using a single derivative with altered growth or survival characteristics. In the first exposure, the clinical isolate 2030SR represented $66 \%$ of the total Vibrio parahaemolyticus flora in the tank water at $t=0$ (Fig. 5A). After $48 \mathrm{~h}$, the total number of $V$. parahaemolyticus in pooled hemolymph was $1.6 \times 10^{3} \mathrm{CFU} \mathrm{ml}{ }^{-1}$, of which $87 \pm 12 \%$ was the clinical isolate. This figure was significantly higher than the initial percentage $(66 \%)$ in the tank water. The total number of $V$. parahaemolyticus in pooled tissue homogenate was $2.0 \times 10^{4} \mathrm{CFU} \mathrm{ml}^{-1}$, of which $80 \pm 8 \%$ was the clinical isolate; this result was also significantly higher than the initial $66 \%$ in the tank water (Fig. 5A).

In the second exposure, the clinical isolate 2030SN represented $36 \%$ of the total Vibrio parahaemolyticus flora in the tank water at $t=0$ (Fig. 5b). After $48 \mathrm{~h}$, the total number of $V$. parahaemolyticus in hemolymph 


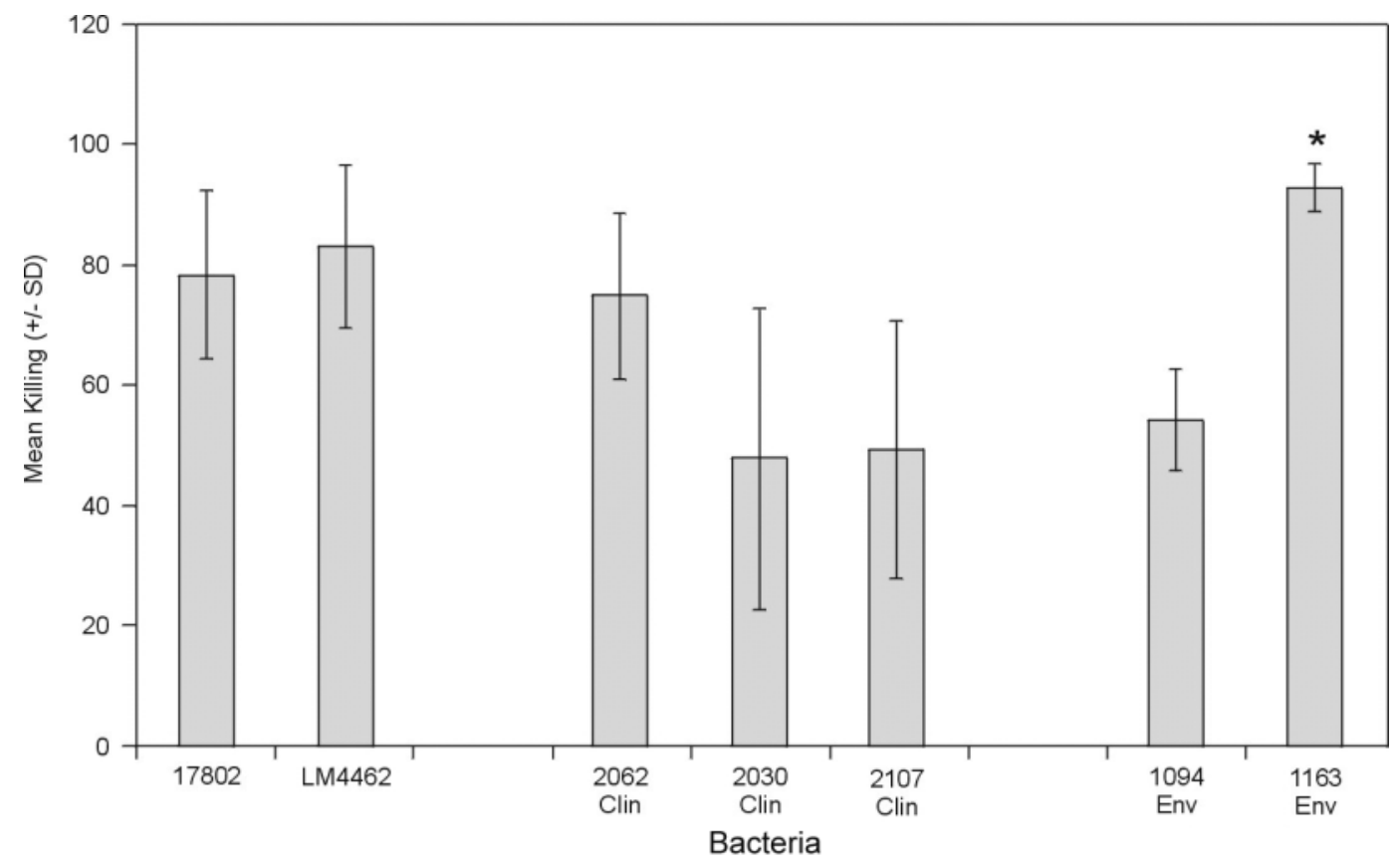

Fig. 4. Mean $( \pm$ SE) killing index (KI) for oyster hemocytes incubated with 2 environmental (Env) Vibrio parahaemolyticus isolates and 3 clinical (Clin) V. parahaemolyticus isolates from patients with gastroenteritis. Isolates were compared to ATCC type strain 17802 and a transposon mutant (LM4462, Fix-Tra) that is unable to switch to an opaque phenotype. ${ }^{*}$ Significant ( $\left.<0.05\right)$ difference between mean hemocyte killing of isolate 1163 from mean hemocyte killing of the other clinical and environmental isolates
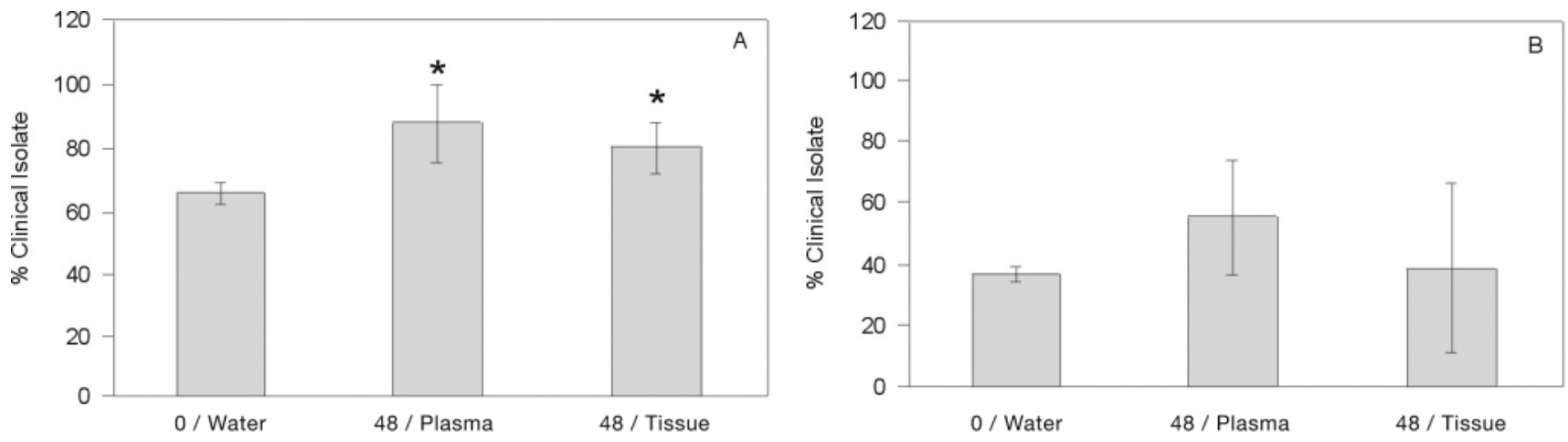

Fig. 5. Percentage of clinical isolate recovered in water, plasma and tissue relative to total Vibrio parahaemolyticus added (clinical + environmental isolate). (A) Clinical isolate 2030SR added in combination with environmental isolate 1163SN and (B) clinical isolate 2030SN added in combination with environmental isolate 1163SR. * Significant $(p<0.05)$ difference between percentage clinical isolate in plasma or tissue after $48 \mathrm{~h}$ and percentage in the water at the beginning of the experiment

was $4.0 \times 10^{3} \mathrm{CFU} \mathrm{ml}{ }^{-1}$, of which $55 \pm 18 \%$ was the clinical isolate; this result was significantly higher than the initial $36 \%$ in the tank water. $V$. parahemolyticus count in tissue homogenate was $3.9 \times 10^{4} \mathrm{CFU} \mathrm{ml}^{-1}$, of which $39 \%$ were the clinical isolate; this result was not significantly different from the initial $36 \%$ in the tank water.

In both exposure experiments no Vibrio parahaemolyticus were isolated from hemolymph or tissue of unexposed oysters. All colonies appearing on TCBS agar plates were resistant to streptomycin.

\section{DISCUSSION}

Previous studies implied an association among vibrio pathogenicity, hemolysins, bacterial encapsulation and the ability of vibrios to resist mammalian or invertebrate defenses (Yoshida et al. 1985, Harris-Young et al. 1995, Genthner et al. 1999). In this study, clinical isolates appeared to be more readily ingested, or less readily disposed of, by oysters during 2 d laboratory exposures. The experiments described here suggest an association between bacterial encapsulation and resis- 
tance to invertebrate defenses, but reveal exceptions to putative associations of encapsulation with pathogenicity or $t d h$ gene expression.

The AP-labeled and DIG-labeled th gene probes used in this study are specific for Vibrio parahaemolyticus (McCarthy et al. 1999) and detected the th gene in both clinical (fecal) and environmental (shellfish) isolates. The $t d h$ gene probe is specific for pathogenic V. parahaemolyticus (McCarthy et al. 2000) and detected the $t d h$ gene only in the clinical isolates (2030, 2062 and 2107). There was $100 \%$ agreement between probe and PCR results for both genes. The clinical isolates used in this study were among 28 cultured from patients suffering from gastroenteritis after eating raw oysters harvested from Galveston Bay during May 1998. The 28 isolates were characterized by pulse-field gel electrophoresis and exhibited the same pattern (Daniels et al. 1999). Regardless, we observed phenotypic differences among the 3 clinical isolates, which were manifested as variable colonial morphologies and a lack of capsular material associated with isolate 2062.

The production of capsular material in Vibrio vulnificus depends on a variety of factors, including medium and temperature (Tamplin et al. 1985, Yoshida et al. 1985). A variety of capsular types may be produced (Reddy et al. 1992, Simonson \& Siebeling 1993) and a direct correlation exists between encapsulation and virulence (Yoshida et al. 1985). Although it did not appear that $V$. parahaemolyticus isolate 2062 required a capsule to be virulent, the presence of capsular material may confer some increased pathogenicity by protecting the bacterium from recognition or destruction by host defenses. This possibility was shown in previous studies using $V$. vulnificus (Tamplin et al. 1985, Yoshida et al. 1985, Biosca et al. 1993) and is underscored by the results obtained here with $V$. parahaemolyticus; i.e., isolate 1163 that lacked capsular material exhibited significantly greater susceptibility to in vitro killing by oyster hemocytes than encapsulated isolates (1094, 2107 and 2030) (Fig. 4).

Colony morphology and the presence of a bacterial capsule appear to be linked in Vibrio parahaemolyticus. Unlike the opaque characteristic found for V. vulnificus (Yoshida et al. 1985), external polysaccharide layers or putative capsules were found by TEM in large, diffuse colonies of $V$. parahaemolyticus. It is not certain whether diffuse colonies are the consequence of encapsulation since swarming behavior is also known to influence this characteristic (McCarter 1998). Regardless, colony morphology, which varies greatly in $V$. parahaemolyticus, can provide only an indication of encapsulation whereas TEM allows a more definitive characterization with a higher level of resolution. Colony morphologies of isolates 1094, 2107 and 2030 were larger and more diffuse than colony morphologies of isolates 1100, 1163 and 2062 (Fig. 1). These results corresponded well with TEM examination of the same isolates grown in both liquid and solid media, where encapsulation was detected for strains 1094, 2107 and 2030 only (Table 3 ). This comparison not only shows a link between colony morphology and encapsulation, but also reveals 2 exceptions to the typical relation between encapsulation and pathogenicity, i.e., an environmental strain (1094) that exhibits a capsule and a clinical strain (2062), possessing the $t d h$ gene, that does not.

In vivo laboratory exposure of oysters to a mixture of clinical (2030) and environmental (1163) isolates showed that both can be incorporated into oysters, with some evidence that the clinical isolate was ingested more readily than the environmental isolate or that it survived better in oyster tissues (Figs 5A \& B). The presence of both isolates in the hemolymph indicated a systemic invasion by the bacteria, which might reflect an ecological association (Tamplin \& Capers 1992). The presence of bacteria in the hemolymph may be a consequence of transport by phagocytic hemocytes between the digestive tract and the hemolymph sinuses (diapedesis). Systemic invasion and persistence in laboratory-exposed oysters, combined with the reduced ability of oyster hemocytes to kill the clinical isolates in vitro, indicated that oyster defenses do not exclude clinical isolates from their tissue. Thus, it is unlikely that selective exclusion or killing by oyster defenses is responsible for the inability to isolate Vibrio parahaemolyticus 03:K6 from Galveston Bay oysters.

Acknowledgements. Isolates of Vibrio parahaemolyticus O3:K6 were obtained through the efforts of Kirk Wiles, Texas Department of Health. We thank P. Zerangue for valuable technical assistance. This study is Contribution No. 1132, National Health and Environmental Effects Research Laboratory and Gulf Ecology Division, 1 Sabine Island Drive, Gulf Breeze, FL 32561, USA.

\section{LITERATURE CITED}

Allam B, Paillard C, Howard A, Le Pennec M (2000) Isolation of the pathogen Vibrio tapetis and defense parameters in brown ring disease Manila clams Ruditapes phillippinarum cultivated in England. Dis Aquat Org 41:105-113

Bag, PK, Nandi S, Bhadra RK, Ramamurthy T, Bhattacharya SK, Nishibuchi M, Hamabata T, Yamasaki S, Takeda Y, Nair GB (1999) Clonal diversity among recently emerged strains of Vibrio parahaemolyticus O3:K6 associated with pandemic spread. J Clin Microbiol 37:2354-2357

Barrow GI, Miller DC (1969) Marine bacteria in oysters purified for human consumption. Lancet 2:421-423

Biosca E, Llorens H, Garay E, Amaro C (1993) Presence of a capsule in Vibrio vulnificus biotype 2 and its relationship to virulence for eels. Infect Immun 61:1611-1618 
Blake PA, Weaver RE, Hollis DG (1980) Diseases of humans (other than Cholera) caused by Vibrios. Annu Rev Microbiol 34:341-367

Chowdhury MAR, Yamanaka H, Miyoshi S, Shinoda S (1990) Ecology and seasonal distribution of Vibrio parahaemolyticus in aquatic environments of a temperate region. FEMS Microbiol Ecol 74:1-10

Chu FLE (1988) Humoral defense factors in marine bivalves. Am Fish Soc Spec Publ 18:178-188

Daniels NA, Ray B, Easton A, Marano N, Kahn E, McShan A, Del Rosario L, Baldwin T, Kingsley M, Puhr N, Wells J, Cameron D, Griffin P, Tauxe R, Angulo F (1999) Large multistate outbreak of oyster-associated Vibrio parahaemolyticus infections: emergence of virulent serotype highlights prevention quandary. J Gen Intern Med 14:23

De Paola A, Hopkins LH, Peeler JT, Wentz B, Mc Phearson RM (1990) Incidence of Vibrio parahaemolyticus in United States coastal water and oysters. Appl Environ Microbiol 56:2299-2302

De Paola A, McLeroy S, McManus G (1997) Distribution of Vibrio vulnificus phage in oyster tissues and other estuarine habitats. Appl Environ Microbiol 63:2464-2467

Earle PM, Crisley FD (1975) Isolation and characterization of Vibrio parahaemolyticus from cape cod soft shell clams (Mya arenaria). Appl Microbiol 29:635-640

Eyles MJ, Davey GR (1984) Microbiology of commercial depuration of the Sydney rock oyster, Crassostrea commercialis. J Food Prot 47:703-706

Fassel TA, Schaller MJ, Remsen CC (1992) Comparison of alcian blue and ruthenium red effects on preservation of outer envelope ultrastructure in methanotrophic bacteria. Microsc Res Tech 20:87-94

Feng SY (1988) Cellular defense mechanisms of oysters and mussels. Am Fish Soc Spec Publ 18:153-168

Fisher WS (1986) Structure and functions of oyster hemocytes. In: Brehelin $M$ (ed) Immunity in invertebrates. SpringerVerlag, Berlin, p 25-35

Fletcher GC, Scott PD, Hay BE (1991) The depuration of pacific oysters (Crassostrea gigas). In: Otwell WS, Rodrick GE, Martin RE (ed) Molluscan shellfish depuration. CRC Press, Inc., Boca Raton, p 227-238

Fujino T, Sakazaki R, Tamura K (1974) Designation of the type strain of Vibrio parahaemolyticus and description of 200 strains of the species. Int J Syst Bacteriol 24:447-449

Galtsoff PS (1964) The American oyster Crassostrea virginica Gmelin. US Fish Wildlife Serv Fish Bull 64:1-480

Gannon VJ, King RK, Kim JY, Thomas EJG (1992) Rapid and sensitive method for detection of shiga-like toxin-producing Escherichia coli in ground beef using the polymerase chain reaction. Appl Environ Microbiol 58:3809-3815

Genthner FJ, Volety AK, Oliver LM, Fisher WS (1999) Factors influencing in vitro killing of bacteria by hemocytes of the eastern oyster (Crassostrea virginica). Appl Enivron Microbiol 65:3015-3020

Greenberg EP, Dubois M, Palhof B (1982) The survival of marine vibrios in Mercenaria mercenaria, the hardshell clam. J Food Saf 4:113-123

Harris-Young L, Tamplin ML, Fisher WS, Mason JW (1993) Effects of physicochemical factors and bacterial colony morphotype on association of Vibrio vulnificus with hemocytes of Crassostrea virginica. Appl Environ Microbiol 59: 1012-1017

Harris-Young L, Tamplin ML, Mason JW, Aldrich HC, Jackson JK (1995) Viability of Vibrio vulnificus in association with hemocytes of the American oyster (Crassostrea virginica). Appl Environ Microbiol 61:52-57

Honda T, Ni Y, Miwatani T (1988) Purification and character- ization of a hemolysin produced by a clinical isolate of Kanagawa phenomenon-negative Vibrio parahaemolyticus and related to the thermostable direct hemolysin. Infect Immun 56:961-965

Janda JM, Powers C, Bryant RG, Abbott SL (1988) Current perspectives on the epidemiology and pathogenesis of clinically relevant Vibrio spp. Clin Microbiol Rev 1: 245-267

Jones SH, Howell TL, O'Neill KR (1991) Differential elimination of indicator bacteria and pathogenic Vibrio sp. from eastern oysters (Crassostrea virginica Gmelin, 1791) in a commercial controlled purification facility in Maine. J Shellfish Res 10:105-112

McCarter LL (1998) OpaR, a homolog of Vibrio harveyi LuxR, controls opacity of Vibrio parahaemolyticus. J Bacteriol 180:3166-3173

McCarthy SA, DePaola A, Cook DW, Kaysner CA, Hill WE (1999) Evaluation of alkaline phosphatase- and digoxigenin-labeled probes for detection of the thermolabile hemolysin (tlh) gene of Vibrio parahaemolyticus. Lett Appl Microbiol 28:66-70

McCarthy SA, DePaola A, Kaysner CA, Hill WE, Cook DW (2000) Evaluation of non-isotopic DNA hybridization methods for detection of the $t d h$ gene of Vibrio parahaemolyticus. J Food Prot 63:1660-1664

Metcalf TG, Mullen B, Eckerson D, Moulton E, Larkin EP (1979) Bioaccumulation and depuration of enteroviruses by the soft-shelled clam, Mya arenaria. Appl Environ Microbiol 38:275-282

Miliotis MD, Tall BD, Gray RT (1995) Adherence to and invasion of tissue culture cells by Vibrio hollisae. Infect Immun 63:4959-4963

Motes ML, DePaola A, Cook DW, Veazey JE, Hunsucker JC, Garthright WE, Blodgett RJ, Chirtel SJ (1998) Influence of water temperature and salinity on Vibrio vulnificus in northern gulf and Atlantic coast oysters (Crassostrea virginica). Appl Environ Microbiol 64:1459-1465

Nishibuchi M, Kaper JB (1985) Nucleotide sequence of the thermostable direct hemolysin gene of Vibrio parahaemolyticus. J Bacteriol 162:558-564

Okuda J, Ishibashi M, Hayakawa E, Nishino T, Takeda $\mathrm{Y}_{\text {, }}$ Mukhopadhyay AK, Garg S, Bhattacharya SK, Nair GB, Nishibuchi M (1997) Emergence of a unique O3:K6 clone of Vibrio parahaemolyticus in Calcutta, India, and isolation of strains from the same clonal group from Southeast Asian travelers arriving from Japan. J Clin Microbiol 35: 3150-3155

Oliver JD, Warner RA, Cleland DR (1983) Distribution of Vibrio vulnificus and other lactose-fermenting vibrios in the marine environment. Appl Environ Microbiol 45:985-988

Power UF, Collins JK (1989) Differential depuration of poliovirus, Escherichia coli, and a coliphage by the common mussel, Mytilus edulis. Appl Environ Microbiol 55: $1386-1390$

Reddy GP, Hayat U, Abeygunawardana C, Fox C, Wright AC, Maneval DR Jr, Bush CA, Morris JG Jr (1992) Purification and determination of the structure of capsular polysaccharide of Vibrio vulnificus M06-24. J Bacteriol 174: $2620-2630$

Reynolds ES (1963) The use of lead citrate at high pH as an electron opaque stain in electron microscopy. J Cell Biol 17:298-342

Richards GP (1988) Microbial purification of shellfish: a review of depuration and relaying. J Food Prot 51:218-251

Shirai H, Ito H, Hirayama T, Nakamoto Y, Nabakayashi N, Kumagai K, Takeda Y, Nishibuchi M (1990) Molecular epidemiologic evidence for association of thermostable 
direct hemolysin (TDH) and TDH-related hemolysin of Vibrio parahaemolyticus with gastroenteritis. Infect Immun 58:3568-3573

Simonson JG, Siebeling RJ (1993) Immunogenicity of Vibrio vulnificus capsular polysaccharides and polysaccharideprotein conjugates. Infect Immun 61:2053-2058

Simpson LM, White VK, Zane SF, Oliver JD (1987) Correlation between virulence and colony morphology in Vibrio vulnificus. Infect Immun 55:269-272

Son NT, Fleet GH (1980) Behavior of pathogenic bacteria in the oyster, Crassostrea commercialis, during depuration, re-laying and storage. Appl Environ Microbiol 40: 994-1002

Tamplin ML (1994) The ecology of Vibrio vulnificus. In: Watkins W, McCarthy S (ed) Proceedings of the 1994 Vibrio vulnificus Workshop. Office of Seafood, Washington, DC

Tamplin ML, Capers GM (1992) Persistence of Vibrio vulnificus in tissues of Gulf Coast oysters, Crassostrea virginica, exposed to seawater disinfected with UV light. Appl Environ Microbiol 58:1506-1510

Tamplin ML, Rodrick GE, Blake JH, Cuba T (1982) Isolation and characterization of Vibrio vulnificus from two Florida estuaries. Appl Environ Microbiol 44:1466-1470

Tamplin ML, Specter S, Rodrick GE, Friedman H (1985) Vibrio vulnificus resists phagocytosis in the absence of serum opsonins. Infect Immun 49:715-718

Taniguchi H, Ohta H, Ogawa M, Mizuguchi Y (1985) Cloning and expression in Escherichia coli of Vibrio parahaemo-

Editorial responsibility: James Hollibaugh,

Athens, Georgia, USA lyticus thermostable direct hemolysins and thermolabile hemolysin genes. J Bacteriol 162:510-515

Taniguchi H, Hirano H, Kubomura S, Higashi K, Mizuguchi Y (1986) Comparison of the nucleotide sequences of the genes for the thermostable direct hemolysin and the thermolabile hemolysin from Vibrio parahaemolyticus. Microb Pathog 1:425-432

Varga S, Hirtle WA (1975) Incidence of Vibrio parahaemolyticus in fish, shellfish, mud, water, and fish products in Canadian Maritime Region. J Fish Res Board Can 32: 541-544

Volety AK, Oliver LM, Genthner FJ, Fisher WS (1999) A rapid tetrazolium dye reduction assay to assess the bactericidal activity of oyster (Crassostrea virginica) hemocytes against Vibrio parahaemolyticus. Aquaculture 172: 205-222

Wong HC, Liu SH, Wang TK, Lee CL, Chiou CS, Liu DP, Nishibuchi M, Lee BK (2000) Characteristics of Vibrio parahaemolyticus 03:K6 from Asia. Appl Environ Microbiol 66:3981-3986

Wright AC, Morris JG Jr (1991) The extracellular cytolysin of Vibrio vulnificus: inactivation and relationship to virulence in mice. Infect Immun 59:192-197

Wright AC, Simpson LM, Oliver JD, Morris JG Jr (1990) Phenotypic evaluation of acapsular transposon mutants of Vibrio vulnificus. Infect Immun 58:1769-1773

Yoshida S, Ogawa M, Mizuguchi Y (1985) Relation of capsular materials and colony opacity to virulence of Vibrio vulnificus. Infect Immun 47:446-451

Submitted: February 8, 2001; Accepted: May 9, 2001

Proofs received from author(s): July 31, 2001 